This item was submitted to Loughborough's Research Repository by the author.

Items in Figshare are protected by copyright, with all rights reserved, unless otherwise indicated.

\title{
RoMEO Studies 2: how academics want to protect their open-access research papers
}

PLEASE CITE THE PUBLISHED VERSION

PUBLISHER

Sage

LICENCE

CC BY-NC-ND 4.0

REPOSITORY RECORD

Gadd, Elizabeth A., Steve Probets, and Charles Oppenheim. 2019. "Romeo Studies 2: How Academics Want to Protect Their Open-access Research Papers". figshare. https://hdl.handle.net/2134/280. 
RoMEO Studies 2: How academics want to protect their open-access research papers

Elizabeth Gadd, Charles Oppenheim, and Steve Probets

Department of Information Science, Loughborough University, Loughborough, LE11 3TU

Correspondence to Professor Charles Oppenheim, Department of Information Science, Loughborough

University, Loughborough, LE11 3TU, UK. Email: C.Oppenheim@lboro.ac.uk

This article has been accepted for publication in the Journal of Information Science.

\begin{abstract}
This paper is the second in a series of studies (see Gadd, E., C. Oppenheim, and S. Probets. RoMEO Studies 1: The impact of copyright ownership on author-self-archiving. Journal of Documentation. 59(3) 243-277) emanating from the UK JISC-funded RoMEO Project (Rights Metadata for Open-archiving). It considers the protection for research papers afforded by UK copyright law, and by e-journal licences. It compares this with the protection required by academic authors for open-access research papers as discovered by the RoMEO academic author survey. The survey used the Open Digital Rights Language (ODRL) as a framework for collecting views from 542 academics as to the permissions, restrictions, and conditions they wanted to assert over their works. Responses from self-archivers and non-archivers are compared. Concludes that most academic authors are primarily interested in preserving their moral rights, and that the protection offered research papers by copyright law is way in excess of that required by most academics. It also raises concerns about the level of protection enforced by e-journal licence agreements.
\end{abstract}

\title{
Introduction
}

In the era of print, the usage of research papers (in the form of journal articles or conference papers) was governed by copyright law alone. Publishers and authors did not try to impose additional restrictions on the use of their works, and if users wished to make more liberal use of them, they would either have to take out a copyright licence such as those provided by the UK Copyright Licensing Agency [1] (CLA) or negotiate directly with the rights holder. As we moved into the electronic era, copyright law still protected works in digital media by virtue of them being in 'fixed form'. However, the electronic era saw a new departure for the distribution of such copyright works: instead of them being sold outright to purchasers in parallel with their print equivalents, publishers began to licence access to them instead. The licensing phenomenon has been much discussed [2,3] and is not the focus of this paper. However, one of the most significant consequences of licensing was that the usage of such licensed works was no longer solely governed by copyright law, but by the terms of the licence agreement signed by the subscriber [4].

Whilst it was hoped that the introduction of electronic delivery methods would reduce the cost of scholarly journals, that did not prove to be the case [5]. In many cases, libraries found they were paying much more, firstly, by virtue of having to pay twice for both the printed and the electronic version, and secondly, as a result of publishers 'bundling' together their electronic titles and selling them on a 'take it or leave it' basis [6]. However, the possibilities for improving the scholarly communication chain provided by electronic delivery methods did not go unnoticed and the open-access movement began to propound the benefits of free web-based access to the research literature.

Two models are proposed by the open access movement: 1) freely available electronic journals, and 2) author self-archiving of research papers on institutional or subject-based repositories (such as ArXiv [7]). Although they are seen as complementary, the institutional repository model has been promoted as the fastest way to make open access a reality [8]. If the current scholarly journal literature became openaccess overnight (and there are estimates that this consists of 2,000,000 articles per annum [9]) there would undoubtedly be enormous benefits. However, it would leave the scholarly journal literature facing the same problems that other open-access web pages have faced since the birth of the Internet, namely, the misunderstanding that 'publicly available' means 'in the public domain'. Of course, while the protection of copyright law still technically applies to web pages, there is a common misconception that posting to the internet gives end-users an 'implied licence' to use - or abuse. Concerns about abuse have lead many web-based information providers to invest in digital rights management systems to provide 
technical protection for their copyright material [10]. There has also been a proliferation of "clickthrough' licences which force end-users to agree to conditions of use [11]. However, discussions about the best way of protecting the copyright in web-based scholarly literature may be premature. Who is to say that academic authors wish to assert and protect the rights that copyright law grants them over their works?

The development of free-ware and share-ware as software distribution mechanisms brought with them a range of 'alternative' copyright regimes by which those works could be protected. The most prominent is the GNU Public Licence [12] (GPL) which states that whilst software may be copied and re-used, any resulting derivatives must be made available under the same generous terms as the source software. A number of other alternative regimes are now being developed for other types of work. Such initiatives suggest that whilst restrictive copyright protection may not be appropriate to open access works, a certain level of protection is still required: creators are not prepared simply to bequeath their works to the public domain. One approach adopted by the Creative Commons initiative [13] is to develop a series of licences by which creators wishing to make their works freely available can afford them some protection in an open access environment, whilst not restricting usage to the limited provisions (exceptions) allowed under copyright legislation. Linked to the Creative Commons licences are simple human-readable 'commons deeds' and related rights metadata.

The UK JISC-funded (Joint Information Systems Committee) RoMEO (Rights Metadata for Openarchiving) project [14], inspired by such initiatives, set about to determine exactly how academics wanted to protect their freely available research papers, in order to inform the development of some rights metadata of specific relevance to this sub-set of 'give-away' literature. The resulting survey instrument was also designed to ascertain how academics used others' freely available research papers to see if there was any disparity between academics-as-authors and academics-as-users. This is discussed in the third of the RoMEO Studies series [15]. This paper investigates the protection afforded scholarly research papers by the UK Copyright Designs and Patents Act 1988 [16] (CDPA 1988) and electronic journal licences. It then considers how the two compare with the RoMEO academic author survey results as to how academics want to protect their own freely available research papers.

\section{Methods adopted}

The online survey was divided into three sections: A - About You, B - Your research papers, and C How you use other peoples' research papers. Section A collected demographic information. Section B collected information on how academics wished to protect their own freely available research papers and Section C collected information on how academics usually used other peoples' research papers.

To provide a framework for collecting information for sections $\mathrm{B}$ and $\mathrm{C}$, we looked to an existing Digital Rights Expression Language (DREL). DRELs provide models for expressing rights and permissions information over content. The chosen DREL was the Open Digital Rights Language [17] (ODRL). This provides a model of permissions, constraints and requirements over works. A constraint is a restriction or limit on the extent of the permission being offered (e.g., you may print, but only four times), whereas a requirement is a condition under which the permission may be performed (e.g., you may print four times, if you pay a fee). It was felt that the terms "constraint" and "requirement" would be better represented to respondents by "restriction" and "condition". The remainder of this article uses these terms. Appendix 1 illustrates: a) the available ODRL terms (permissions, restrictions and conditions); b) which were chosen as of possible relevance to the giveaway literature in question; and c) how the terms were described in the questionnaire (some terms were re-worded to make more sense to respondents).

The only regret about the choice of terms was that 'ReContext' was not selected. It was felt that recontexting of research papers mainly occurred through aggregation (of a paper within a coursepack or book for example). (Aggregation was included as a permission.) However, recontexting could also refer to the mounting of a research paper in an unsuitable domain (say a far right propagandist web site) which may not be considered aggregation.

The questionnaire was piloted on a selection of academics in the Department of Information Science at Loughborough University, and on members of the project Advisory Board. Amendments were made and 
the final version mounted on the project web site in September 2002. The questionnaire was then advertised on a number of discussion lists, as well as being mounted on all of the ArXiv (physics subjectbased eprint archive) mirror sites.

\section{The use of research papers allowed by UK copyright law}

Lessig divides all activities that may be performed with a copyright work into three categories:

unregulated, regulated and copyright [18]. Unregulated activities are those about which copyright law is silent (throwing a copyright work out of the window is an unregulated activity). Regulated activities are those that may be performed in certain circumstances (such as copying a journal article). 'Copyright' activities are those that are the exclusive right of the copyright holder and may not be done without explicit permission. The UK Copyright Designs and Patents Act of 1988 states that a copyright holder has the following exclusive rights:

\section{$16(1)$}
(a) to copy the work
(b) to issue copies of the work to the public
(ba) to rent or lend the work to the public
(c) to perform, show or play the work in public
(d) to broadcast the work...
(e) to make an adaptation of the work or do any of the above in relation to an adaptation.

This list is an exhaustive one and some things are notable by their absence. For example, viewing or reading a work are unregulated activities. The activities listed can only be performed by users if: a) there is an exception in law to these rights (regulated activities), or b) they have the permission of the copyright holder ('copyright' activities).

There are a number of exceptions to a copyright holder's rights outlined in Chapter III of the UK Act. The three groups of relevance to 'literary works' are entitled, i) general, ii) education, and iii) libraries and archives. The following sections are of particular relevance to the use of journal articles (the format that most research papers take).

- Fair dealing for the purposes of research or private study (s.29);

- Fair dealing for the purposes of criticism, review and news reporting (s. 30);

- Things done for the purpose of instruction or examination (s.32);

- The inclusion of no more than two excerpts in an anthology for educational use (s.33);

- Performing the work in the course of activities of an educational establishment (s.34)

- Copying by Librarians of an article in a periodical or part of a published work for supply to users, subject to multiple copy restrictions (ss. 38, 39 and 40);

Whilst the exceptions allowed by teachers and librarians are fairly well defined - if narrow in scope - it is frustrating for academics that the general 'fair dealing' defences on which they are most likely to rely, are famously vague. The most hotly debated exception is that of 'fair dealing for the purposes of research or private study'. This currently reads:

29.- (1) Fair dealing with a literary, dramatic, musical or artistic work for the purposes of research or private study does not infringe any copyright in the work or, in the case of a published edition, in the typographical arrangement.

However, once the EU Copyright Directive is implemented in the UK, it is likely that this clause is changed to

"29.- (1) Fair dealing with a literary, dramatic, musical or artistic work for the purposes of research for a non-commercial purpose does not infringe any copyright in the work provided that it is accompanied by a sufficient acknowledgement." (Our emphasis) 
The following new clauses will also be added;

(1B) No acknowledgement is required in connection with fair dealing for the purposes mentioned in subsection (1) where this would be impossible for reasons of practicality or otherwise.

(1C) Fair dealing with a literary, dramatic, musical or artistic work for the purposes of private study does not infringe any copyright in the work."[19]

Thus a distinction is being drawn between non-commercial and commercial research, and between research and private study. The purpose of copying will thus become more significant. However, the very concept of 'fair dealing' has always been, and will continue to remain, undefined.

\section{Fair dealing guidelines}

A number of groups have made an effort to interpret 'fair dealing' for users. Back in 1990, the British Copyright Council (BCC) published some guidelines written by Clark. They stated that whilst photocopying one chapter or $5 \%$ of a book constituted 'fair dealing', photocopying a single journal article did not [20]. The import of this advice has been much debated, and it is understood that the BCC expect to revise these guidelines: they are certainly no longer available on their web pages.

In 2000, the CLA produced a leaflet entitled Fair dealing and library privilege [21] which repeated the BCC guidelines on both books and journal articles written ten years before. They argued that copyright holders get income from copying permission fees, therefore if someone copies without paying the fee it amounts to stealing: "and stealing is not fair. If it is not fair, it is not fair dealing."

However, again, the CLA has now withdrawn these guidelines and their fair dealing web page is currently unavailable "while it is being updated". Their re-evaluation of the meaning of fair dealing may have been influenced by the outcome of the recent Copyright Tribunal case where Floyd QC decided the photocopying of a journal article by a student was likely to amount to fair dealing [22].

As the meaning of fair dealing had caused so much uncertainty in the print environment, in 1998 the JISC and the Publishers Association (PA) agreed to produce guidance on what could be considered fair dealing in the electronic environment. The resulting JISC/PA Guidelines for Fair Dealing in an Electronic Environment [23] offer the following advice for users:

1. Any incidental copying to disk involved in the viewing of part or all of an electronic publication is fair dealing.

2. It is fair dealing for an individual to print onto paper one copy of part of an electronic publication [e.g., one journal article].

3. It is fair dealing for an individual to copy onto disk part of an electronic publication for permanent local electronic storage, where the disk is either a portable medium, or a fixed medium accessible to only one user at a time.

Whilst the Guidelines are only advice, the fact that they have been agreed upon by rights holders and users alike provides some assurance of their reliability. The guidelines also re-open the debate on fair dealing in the print environment. If publishers are happy for users to print out an entire article from an electronic journal, would they not also be happy for users to photocopy an entire article from a printed journal?

\section{Summary of UK copyright provisions for research papers}

Table 4 below summarises the activities that are permitted with a journal article under the CDPA 1988 and the restrictions and conditions imposed upon those activities.

\begin{tabular}{|l|l|}
\hline Permission & Restrictions and conditions \\
\hline Photocopy & One copy; of one article per journal issue; for non-commercial research or private \\
\hline
\end{tabular}




\begin{tabular}{|l|l|}
\hline & $\begin{array}{l}\text { study; subject to acknowledgement; as long as it doesn't result in "copies of } \\
\text { substantially the same material being provided to more than one person at } \\
\text { substantially the same time for substantially the same purpose". }\end{array}$ \\
\hline Photocopy & $\begin{array}{l}\text { One copy; of one article per journal issue; by a Librarian: of a prescribed library; for } \\
\text { a user; that has signed a declaration form; and paid a sum no less than the cost of } \\
\text { it's production; for non-commercial research or private study; as long as the user's } \\
\text { requirement is not related to any similar requirement of another person. }\end{array}$ \\
\hline Print & One copy; of one article per journal issue; for research or private study. \\
\hline Save & One copy; of one article per journal issue; for research or private study. \\
\hline $\begin{array}{l}\text { Copy } \\
\text { (unspecified) }\end{array}$ & For the purpose of criticism and review - subject to acknowledgement \\
\hline $\begin{array}{l}\text { Copy } \\
\text { (unspecified) }\end{array}$ & For the purpose of reporting current events - subject to acknowledgement \\
\hline $\begin{array}{l}\text { Copy } \\
\text { (unspecified) }\end{array}$ & For the purposes of examination by the way of setting questions \\
\hline $\begin{array}{l}\text { Non-reprographic } \\
\text { copy }\end{array}$ & $\begin{array}{l}\text { In the course of instruction or of preparation for instruction; by a person giving or } \\
\text { receiving instruction }\end{array}$ \\
\hline Excerpt & $\begin{array}{l}\text { A short passage; from a work not itself intended for use in educational } \\
\text { establishments; in an anthology consisting mainly of non-copyright material; for use } \\
\text { in educational establishments; subject to acknowledgement; no more than two } \\
\text { excerpts from works by the same author in collections published by the same } \\
\text { publisher over any period of five years. }\end{array}$ \\
\hline $\begin{array}{l}\text { Perform (e.g. in a } \\
\text { lecture) }\end{array}$ & $\begin{array}{l}\text { Before an audience of teachers and pupils; at an educational establishment; by a } \\
\text { teacher or pupil in the course of activities of the establishment OR by any person for } \\
\text { the purposes of instruction. }\end{array}$ \\
\hline
\end{tabular}

Table 4 Summary of UK CDPA 1988 provisions for the use of journal articles

\section{Copyright law in ODRL terms}

In order to compare the protection offered by copyright law with that required by academics, the ODRL permissions, restrictions and conditions listed in the academic survey were compared to those provided by law.

\section{Permissions}

In the print environment, display is (in the Lessig sense) an unregulated activity. However, the new EU Directive will grant rightsholders the exclusive right to communicate a work (electronically) to the public, i.e. distribute over a network. This will make display (in practice) a regulated activity.

UK copyright law does not distinguish between printing and saving, classing them both as copying. Copying is a regulated act. Taking excerpts from works is also a regulated act. Copyright is only infringed if the whole or substantial part is copied (s.16(3)(a)). The term "substantial" refers to quality as well as quantity, so in some circumstances a short excerpt could be considered substantial. However in most circumstances it would not be. The exceptions to copyright do also allow the making of even substantial excerpts in certain cases - e.g., fair dealing for criticism and review.

Under law, giving and even selling a copyright work - assuming you own the original (e.g. have purchased it or had it given to you) - is in one sense an unregulated act by virtue of the "exhaustion of rights' doctrine in the EU [24] and the 'first sale' doctrine in the US [25]. Thus if I purchase a book, I can give or sell it to whomsoever I wish. However, if I make a copy of an article under law, there are provisions preventing me from giving it or selling the copy to other parties, so in this sense it is a regulated act.

Under a Statutory Instrument introduced in 1996 [26] lending became a restricted act if performed by a publicly accessible establishment. (An exception is made for public and 'prescribed' not-for-profit 
libraries). However lending a copyright work on a personal basis is an unregulated act. Leasing, however, described as 'rental' by the Act, is restricted.

Aggregation is of itself an unregulated act under the CDPA 1988. However, certain prerequisites (such as making copies to form the aggregation) are regulated. In addition, aggregations could infringe an author's moral right to object to derogatory treatment of their work [27], for example, if a scholarly article on gynaecology was juxtaposed with pornographic materials. The nearest equivalent to modification in the CDPA 1988 is "adaptation" which is a restricted act. The legality of creating a derivative work would depend on the alterations made to the original. If a 'substantial' part of the original was reproduced in the derivative work, the derivative work would be considered an infringing copy. Annotation could be viewed as a form of modification; however, this activity is of itself unregulated by the CDPA 1988. There are, however, moral rights issues associated with modification and annotation. If the additions amount to 'derogatory treatment' of the work, authors may have the right to object.

Table 5 summarises the ODRL permission elements in use in UK copyright law, and whether they are unregulated, regulated or restricted.

\begin{tabular}{|l|l|}
\hline Permission elements & UK Copyright law \\
\hline Display & REGULATED \\
\hline Print & REGULATED \\
\hline Modify & REGULATED \\
\hline Excerpt & REGULATED \\
\hline Annotate & REGULATED \\
\hline Aggregate & REGULATED \\
\hline Sell & REGULATED \\
\hline Lend & REGULATED \\
\hline Give & REGULATED \\
\hline Lease & RESTRICTED \\
\hline Duplicate & REGULATED \\
\hline Save & REGULATED \\
\hline
\end{tabular}

Table 5 Permissions allowed by copyright law

\section{Restrictions}

Restricting usage to individuals or groups, or for certain purposes is common in the CDPA 1988. Fair dealing is restricted to private (i.e., individual) study, and certain exceptions only apply to certain groups (e.g., librarians). Again, in the case of fair dealing, the number of copies (count) is limited to one. The spatial restriction applies in that the jurisdiction of national copyright laws is limited to a nation's geographical boundaries. Thus, the terms of the CDPA 1988 are limited to the UK, even if as a result of international conventions, there are many similarities between national copyright laws. Date/time restrictions are utilised by the Act as in, for example, the five year restriction in which publishers can incorporate more than two of a particular author's extracts in an anthology.

The quality of copies (in terms of being exact replicas of the original) is a restriction in two ways. Firstly, adapting the work is a restricted act. Secondly, where moral rights have been asserted, the author has the right to object to any "additional to, deletion from or alteration to or adaptation of the work..." (s.80(2)(a)). However, the Act does not insist that copies take the same format as the original.

The new EU Directive provides legal protection for technological measures used by right holders to protect their works. This will soon be implemented into UK law. However, the use of such measures will not become a legal requirement. Thus whilst, watermarks and other security measures will receive added protection, they will not be made compulsory under law.

Table 6 summarises the restrictions in use in UK copyright law. 


\begin{tabular}{|l|l|}
\hline Restriction elements & UK Copyright Law \\
\hline Individual & Y \\
\hline Group & Y \\
\hline Count & Y \\
\hline Spatial & Y \\
\hline DateTime & Y \\
\hline Quality & Y \\
\hline Format & N \\
\hline Watermark & N \\
\hline Purpose & Y \\
\hline
\end{tabular}

Table 6 Restrictions utilised by copyright law

\section{Conditions}

UK copyright law utilises all the conditions listed in the RoMEO academic author survey. The supply of s.38 periodical articles to users involves i) the user accepting terms and conditions in the form of the declaration form; ii) registering and tracking by virtue of the supplying library being required to keep copies of such forms; and iii) payment in the form of "a sum not less than the cost... attributable to their production" (s.38(2)(c)). Attribution in the form of a 'sufficient acknowledgement' is a condition of copying for criticism and review. It is also an author's moral right (s.77(2)).

Table 7 summarises the condition elements in use in copyright law.

\begin{tabular}{|l|l|}
\hline Condition elements & UK Copyright Law \\
\hline Payment & Y \\
\hline Accept & Y \\
\hline Register & Y \\
\hline Attribution & Y \\
\hline Tracked & Y \\
\hline
\end{tabular}

Table 7 Conditions utilised by copyright law

The use of research papers allowed by ejournal licences

The majority of electronic journals (wherein the majority of electronic research papers are to be found) are governed by licence agreements rather than copyright legislation. In the print environment, libraries found it difficult enough to meaningfully convey to users what their copying options were under law, even though one set of regulations applied to all copyright materials. In the electronic environment, with usage conditions varying from resource to resource, communicating those terms to end-users has become even more of a challenge. Investigations for this paper revealed only two organisations that tackled this challenge in any co-ordinated way: the University of Leicester Library [28] in the UK, and Yale University Library [29] in the US. Both institutions had summarised the terms of all their licence agreements for end-users. Yale's listing was produced only as a guideline for library staff. However, Leicester's listing was designed to be an authoritative list which could be depended upon by users.

In an effort to draw some comparison between the protection afforded by UK copyright law, and those afforded by e-journal licences, we performed an analysis of the University of Leicester's listing in August 2002. Leicester had divided up the main categories of activity that the licences covered as follows:

- Single print-outs of articles for personal use made by or on behalf of an authorised user

- Saving single copies of articles to portable disk or non-networked PC for personal use by or on behalf of an authorised user

- Multiple print-outs or photocopies of print outs of articles as class handouts

- Inclusion of multiple print-outs or photocopies of print-outs of articles in Course Packs

- Inclusion of articles in on-line Course Packs

- Sending a single copy of an article by email attachment to another student or member of staff of the University of Leicester for his/her own use. 
The licence terms from 21 electronic journal publishers were listed. The usage they permitted is described in Table 8 below.

\begin{tabular}{|l|l|l|}
\hline Activity & $\begin{array}{l}\text { Number of } \\
\text { publishers that } \\
\text { permit it }\end{array}$ & $\begin{array}{l}\text { Percentage of } \\
\text { publishers }\end{array}$ \\
\hline Single prints for personal use & 21 & $100 \%$ \\
\hline Saving single copies to disk for personal use & 18 & $86 \%$ \\
\hline $\begin{array}{l}\text { Email single copy to authorised user for } \\
\text { personal use }\end{array}$ & $11^{*}$ & $52 \%$ \\
\hline Multiple printed copies for class handouts & 10 & $48 \%$ \\
\hline Multiple printed copies for course packs & $9^{* *}$ & $43 \%$ \\
\hline Online course packs & 7 & $33 \%$ \\
\hline
\end{tabular}

*Five of these stipulate that emails must be sent from and received by 'le.ac.uk' email addresses

** One of which only allows delivery of such packs to campus-based students

\section{Table 8 Ejournal usage permitted by publishers supplying the University of Leicester}

Single print-outs for personal use was the only activity allowed by all e-journal publishers. Eighty-six per cent of publishers allowed downloading to disk. Just over half permitted the emailing of a single copy to an authorised user for personal use (although $45 \%$ of these specified the user must have a local email address). Multiple print-outs for class handouts or coursepacks was permitted by less than half of publishers, and online coursepacks by only one-third. This was an interesting finding, especially as in the US, their 'fair use' exception explicitly includes "multiple copies for classroom use" [30]. It may have been that publishers were not happy for their articles to be 'repackaged', perhaps indicating a concern about aggregating or re-contexting material in a way that the authors (or publishers) would deem inappropriate.

\section{Comparison of ejournal licences and JISC/PA guidelines}

A comparison of the activities that were permitted by Leicester's ejournal licences with those considered to be 'fair dealing' by the JISC/PA group provides some insight into the question of whether licences were more or less restrictive than copyright law. In summary, the JISC/PA guidelines allowed users to:

- Print a single copy of a journal article for research and private study

- Save a single copy of a journal article to disk

- A Librarian can forward an electronic copy to an individual for local storage, but that copy can't be retransmitted

Leicester's listings indicated that while $100 \%$ of publishers allowed printing of single articles, just $86 \%$ of licences allowed the saving of a single copy to disk. Perhaps more alarmingly, only $52 \%$ of licences allowed the forwarding of a single article to an authorised user for personal use.

It is important to bear in mind that some of the licences also allow activities that are not permitted under UK fair dealing interpretations including printed and online coursepacks. However, the fact that almost half of Leicester's publishers prohibit an activity that publishers and librarians have agreed could be considered fair dealing goes give some cause for concern.

\section{Protection for research papers required by academics}

We know of no research that has investigated how academics actually want to protect their research papers. In a previous study we have shown that, by virtue of the custom and practice of Universities in waiving copyright in research outputs, academics own the copyright in their research papers before they assign it to publishers [31]. In order to self-archive research papers, it would be far simpler if academics retain copyright. If they do so, they will then be in a position to set their own terms and conditions over 
the use of their work. Indeed, in order to encourage academics to self-archive, they may need reassurance that they are able to establish such terms and conditions over the use of their work. The RoMEO project proposes the use of rights metadata [32] to provide that reassurance. The RoMEO academic author survey aimed to inform the development of that metadata.

\section{Survey response rate and demographics}

The number of survey respondents and their demographics has been reported in full in the first of the RoMEO Studies series [33]. However, to summarise, 542 responses were received from 57 countries. The majority (one-third) came from the UK. The USA, Australia, Canada and Germany contributed the next largest tranche of respondents representing $17 \%, 4 \%, 3 \%$ and $3 \%$ of the total. It was impossible to calculate the response rate as the sample size was unknown.

Fifty per cent of respondents came from a pure science discipline, with $38 \%$ from a social sciences or humanities discipline, and 12\% from engineering. The largest group of respondents (39\%) had had more than 15 years service in academia, but there was a fairly even distribution of respondents with differing lengths of academic service. Each respondent had published an average (mean) of 42 papers, although the modal average was ten papers or less.

\section{Academics and self-archiving}

Respondents were asked if they had ever made any of their research papers freely available on the web. Five-hundred and thirty-six responded of which 58\% (310) said yes, and 42\% (226) said no. (Those answering 'yes' are referred to as 'archivers' in this paper, and those answering 'no' as 'non-archivers'). This may indicate a bias in the sample resulting from the self-selected nature of the group. The 2002 ALPSP survey of 1,246 authors showed that just $11 \%$ of them deposited their articles "in an electronic preprint archive [34]". The ALPSP question was much narrower than the one posed by this survey (i.e., just referring to preprint archives rather than any freely available web publication), and the audience was much wider (i.e., journal authors in general as opposed to academic authors in particular). However, it was felt appropriate to consider the responses of 'archivers' and 'non-archivers' separately on the matter of the protection they required for their research papers.

\section{How the papers had been made available}

Those who had made research papers available on the web were asked where they had posted them. Four options were given, plus an 'other' category. The options were: your own or departmental web pages; a repository or archive run by your institution; a disciplinary archive (such as ArXiv, or Cogprints); and a freely available electronic journal or conference proceeding. The results are show in Figure 1.

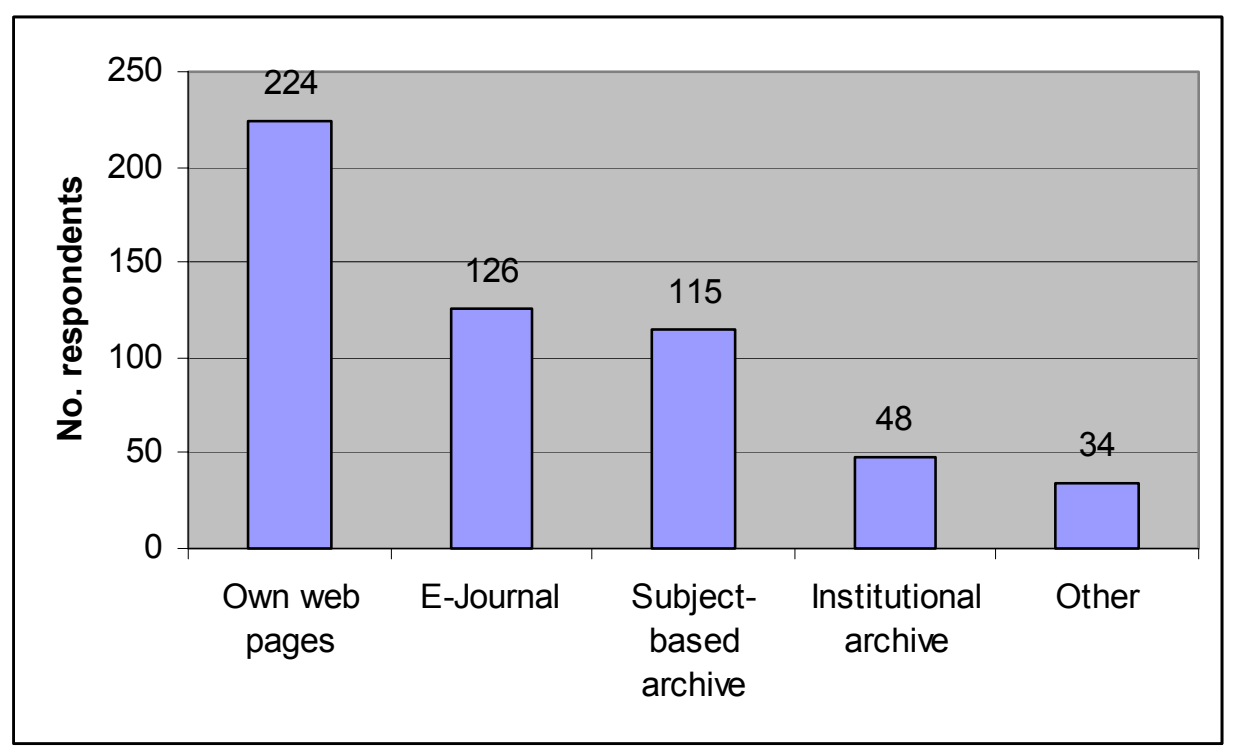


The total number of responses does not add up to the 310 who had previously indicated that they had made research papers freely available on the web because many respondents selected more than one option. By far the most popular location for research papers was on the academic's own web pages. Freely available electronic journals and subject-based archives attained a similar level of popularity with approximately one-third of respondents submitting papers to one of these. Institutional archives were not heavily used, probably because very few are currently available.

Respondents were invited to explain their answers and 68 did so. A number of other locations for research papers were identified. These included a co-author's web site, a teaching and learning site (such as a VLE), archives run by professional bodies or other industry groups, and research group or project web sites.

Even though the survey encompassed papers that had been made freely available on the web through either self-archiving or open-access e-journals, for convenience, the rest of this paper uses the term 'selfarchived' to refer to both. This does not detract from the fact that they are very different approaches. However, this survey was concerned with the protection requirements of academics for any open access research paper whether available via an open access e-journal, institutional repository, or subject-based archive.

\section{Self-archiving concerns}

All respondents (those that self-archived and those that did not) were asked what their main concerns were about making research papers freely available on the web. Six options and an 'other category were given. The options were: 1) I have no concerns, 2) that the work will be plagiarised, 3) that the work will be used for commercial gain, 4) that the integrity of the work will be compromised (i.e. altered in some way), 5) that no journal will subsequently publish it, and 6) that it will break existing copyright agreements with publishers. The results were cross-tabulated with the question, "Have you ever made any of your research papers freely available on the web?", to see if any concerns were peculiar to archivers or non-archivers.

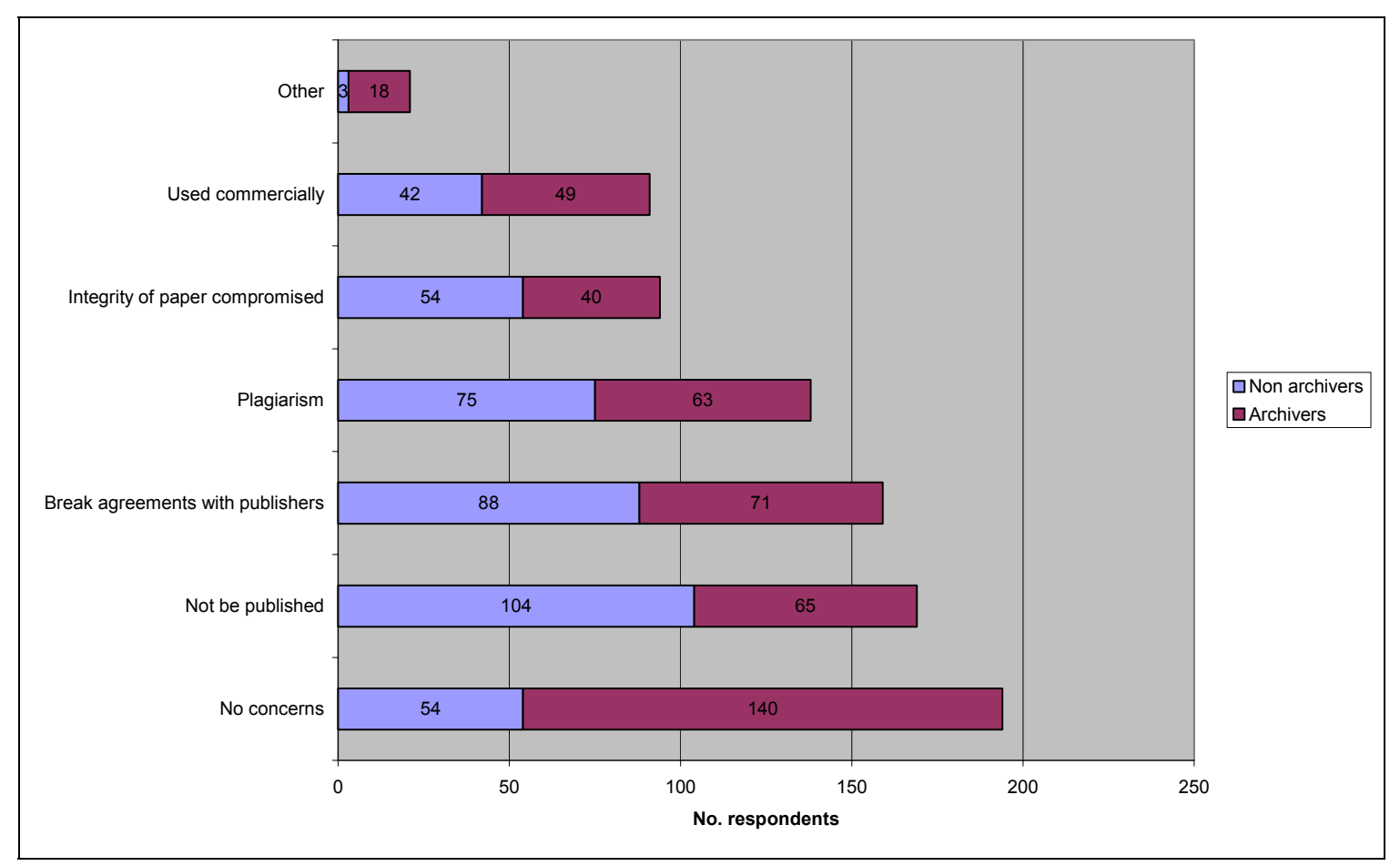

Figure 2 Self-archiving concerns 
It can be seen that the largest group of respondents, 194, had no concerns at all about making their works freely available on the web. (Although two of these had also checked the "integrity" box). Seventy-two per cent of these had previously self-archived.

The major concerns stemmed back to authors' relationships with publishers. One-hundred and sixty-nine respondents, presumably thinking about posting preprints, said they had concerns that having selfarchived they would not then find a publisher that would publish their work. The next largest group, presumably thinking about posting previously published works, said they had concerns that self-archiving such works would break existing agreements with publishers.

Twenty-five per cent of all respondents were concerned about plagiarism. A control question could have asked respondents if they had similar concerns about their papers in subscription-based e-journals. This would have clarified whether the concern related to open access in particular, or the online medium as a whole. Smaller numbers of RoMEO respondents were concerned about the integrity of their texts being compromised, and that they may subsequently be used for commercial gain, but the numbers were not insignificant (17\% of all respondents).

Table 9 below indicates the percentage of archivers and non-archivers that were concerned about each issue.

\begin{tabular}{|l|c|c|c|c|c|c|}
\hline & \multicolumn{3}{|c|}{ Archivers } & \multicolumn{3}{c|}{ Non-archivers } \\
\hline Self-archiving concerns & Rank & Frequency & $\%$ & Rank & Frequency & $\%$ \\
\hline No concerns & 1 & 140 & $45 \%$ & $4=$ & 54 & $24 \%$ \\
\hline Break agreements with publishers & 2 & 71 & $23 \%$ & 2 & 88 & $39 \%$ \\
\hline Not be published & 3 & 65 & $21 \%$ & 1 & 104 & $46 \%$ \\
\hline Plagiarism & 4 & 63 & $20 \%$ & 3 & 75 & $33 \%$ \\
\hline Used commercially & 5 & 49 & $16 \%$ & 6 & 42 & $19 \%$ \\
\hline Integrity of paper compromised & 6 & 40 & $13 \%$ & $4=$ & 54 & $24 \%$ \\
\hline Other & 7 & 18 & $6 \%$ & 7 & 3 & $1 \%$ \\
\hline
\end{tabular}

Table 9 Self-archiving concerns of archivers and non-archivers

The highest ranking result for existing archivers was that they had no concerns. Interestingly the remaining 55\% of archivers did have concerns about self-archiving, although the concerns evidently did not stop them. This may have been because they were concerned about the online medium, not open access or self-archiving itself. For all the issues listed, a higher percentage of non-archivers registered concern than archivers. The highest ranking concern for non-archivers was that they would not be published, and the second ranking concern that they would break existing agreements. Perhaps not surprisingly, the archivers ranked those two concerns the other way round. The larger group were concerned that existing self-archived works were breaking agreements with publishers, and two per cent fewer were concerned about not being formally published. Plagiarism ranked fourth and third respectively for archivers and non-archivers. Non-archivers were more concerned about the potential loss of integrity of their paper than archivers, who were more concerned about commercial exploitation of their work without permission.

The degree of concern felt by the two groups could be measured by the percentage selecting each option. It was interesting therefore to note that whilst $24 \%$ or more of non-archiving respondents were concerned about four issues, less than $24 \%$ of archivers were concerned about all issues. Chi-square tests showed a significant difference at the $1 \%$ level between all archivers and non-archivers concerns except noncommercial use. The most significant difference was between the number of archivers with no concerns about self-archiving, and the number of non-archivers. 


\section{Permissions}

Respondents were asked, "what would you consider to be acceptable use of any articles YOU made freely available on the web?" and were given the list of twelve ODRL permissions as listed in the methodology. They were requested to indicate for each permission whether they would be happy for others to perform that activity with their work "freely", "with limits", or "not at all".



Figure 3 Activities academics would allow with their own research papers

Response rates for each permission varied from 500 for the 'Lease' option to 524 for the 'Display' option (see Table 10). The response rates may themselves indicate the importance or relevance of a particular activity to academics. There may also have been some difficulty with semantics. Respondents for whom English was a second language may have had more confidence interpreting terms such as "print" and "give" than "aggregate" and "lease".

Table 10 indicates in bold the most common preference for each permission.

\begin{tabular}{|l|c|c|c|c|}
\hline & Freely & Limited & Not at all & TOTAL \\
\hline Aggregate & 166 & $\mathbf{2 9 2}$ & 49 & 507 \\
\hline Annotate & 157 & $\mathbf{2 4 5}$ & 108 & 510 \\
\hline Copy & $\mathbf{2 0 2}$ & 195 & 117 & 514 \\
\hline Display & $\mathbf{4 7 1}$ & 48 & 5 & 524 \\
\hline Excerpt & $\mathbf{3 5 5}$ & 148 & 11 & 514 \\
\hline Give & $\mathbf{3 7 5}$ & 116 & 23 & 514 \\
\hline Lease & 97 & $\mathbf{2 1 1}$ & 192 & 500 \\
\hline Lend & $\mathbf{3 4 7}$ & 135 & 28 & 510 \\
\hline Modify & 68 & $\mathbf{2 5 2}$ & 189 & 509 \\
\hline Print & $\mathbf{3 7 8}$ & 127 & 15 & 520 \\
\hline Save & $\mathbf{3 3 4}$ & 130 & 52 & 516 \\
\hline Sell & 43 & 196 & $\mathbf{2 6 8}$ & 507 \\
\hline
\end{tabular}

Table 10 Permissions data table

Table 11 lists the permissions in order of greatest agreement amongst respondents. 


\begin{tabular}{|l|c|c|c|}
\hline \multicolumn{1}{|c|}{ Permission } & $\begin{array}{c}\text { Percentage } \\
\text { agreeing }\end{array}$ & Option & Rank \\
\hline Display & $90 \%$ & Freely & 1 \\
\hline Give & $73 \%$ & Freely & $2=$ \\
\hline Print & $73 \%$ & Freely & $2=$ \\
\hline Excerpt & $69 \%$ & Freely & 4 \\
\hline Lend & $68 \%$ & Freely & 5 \\
\hline Save & $65 \%$ & Freely & 6 \\
\hline Aggregate & $58 \%$ & $\begin{array}{c}\text { Limited or } \\
\text { conditional }\end{array}$ & 7 \\
\hline Sell & $53 \%$ & Not & 8 \\
\hline Modify & $50 \%$ & $\begin{array}{c}\text { Limited or } \\
\text { conditional }\end{array}$ & 9 \\
\hline Annotate & $48 \%$ & $\begin{array}{c}\text { Limited or } \\
\text { conditional }\end{array}$ & 10 \\
\hline Lease & $42 \%$ & $\begin{array}{c}\text { Limited or } \\
\text { conditional }\end{array}$ & 11 \\
\hline Copy & $39 \%$ & Freely & 12 \\
\hline
\end{tabular}

Table 11 Permissions in order of agreement

The majority vote for seven of the 12 options was to allow that activity freely. The permission on which most respondents agreed was display. $90 \%$ of respondents felt this should be allowed freely. Print and give were the next most commonly agreed upon terms. Seventy-three per cent of respondents held that printing and giving should be allowed freely. This is not surprising. E-journal usage surveys have shown that printing is consistently the most common action with an e-journal article [35]. The example provided for 'give' was that "copies may be forwarded to colleagues". Again, this is a common activity amongst academics and may be the reason why most academics make their works available on their personal web pages: where colleagues who know them by name may easily find them.

The majority of respondents were happy to allow others to excerpt from, and lend their works freely. The number of academics that were unhappy with the idea of others' saving their works (e.g., saved to disk) was perhaps surprising. Ten per cent said that this should not happen at all. One-quarter felt that saving should be limited or conditional. It may have been that these respondents share publishers' fears of the potential for infringement offered by an electronic copy as opposed to a printed copy. Although $73 \%$ of respondents wished to allow printing freely, that left just over one-quarter that felt it should be limited or conditional.

Aggregate was the first activity that the majority of respondents felt should be limited or conditional. Fifty-eight per cent agreed on this. One-third were happy for others to freely aggregate their works. The example given for aggregate was "may be compiled into an anthology" which may include commonplace coursepack compilations or re-publishing. The uncertainty may therefore have stemmed from a perceived lack of control over the nature of the aggregation, in particular, what other works the compilation would contain.

The majority of respondents (53\%) were not happy with the idea of others selling their works without permission. Less expected was the eight per cent that felt this could be done freely. Similarly, leasing was not a popular activity amongst respondents. Forty-two per cent felt that this should be a limited or conditional permission. Thirty-eight per cent said they would not be happy with it at all. This is perhaps not surprising as leasing is another a form of commercial gain by a third-party.

Modify and annotate met with a similar response from academics. Fifty per cent and $48 \%$ respectively thought such activities should only be done under certain limits or conditions. Annotation in the print environment (scribbles in the margin of a library text book) may cause little concern to academics. 
However, they may fear loss of control over an electronically annotated work that can be quickly and easily disseminated.

An interesting result was the response to the term copy. Although $39 \%$ said they would allow this freely, $38 \%$ per cent felt it should be limited or conditional. The example given for copy was "mount another copy on the web". This was to distinguish it from a printed copy described by "print" or a personal electronic copy described by "save". The distinctions may have caused problems of interpretation. Those allowing it freely may have viewed copying in the same terms as print or save, both of which the majority allowed freely. Those that felt it should be limited may either have seen copying as a form of republication (mounting my article on their web site without my permission) or they may have equated copying with plagiarism. Copy is a word with many meanings. If I copy from another in a test, I have cheated. If I copy an article from the library, I have pursued an educational goal.

Of course, respondents did not have the option of explaining why they chose the options they did, which could have allowed us to draw conclusions about the level of understanding of each of the terms and their relevance to open access.

\section{Restrictions and conditions}

Respondents were then asked, "What (if any) restrictions or conditions would you want to place on the use of YOUR self-archived works?". They were given the list of ODRL restrictions and conditions and were asked to select from it. In total, 528 respondents answered this question.

\section{Restrictions}

The list contained ten restrictions (including 'no restrictions'). The results are given in Figure 4.

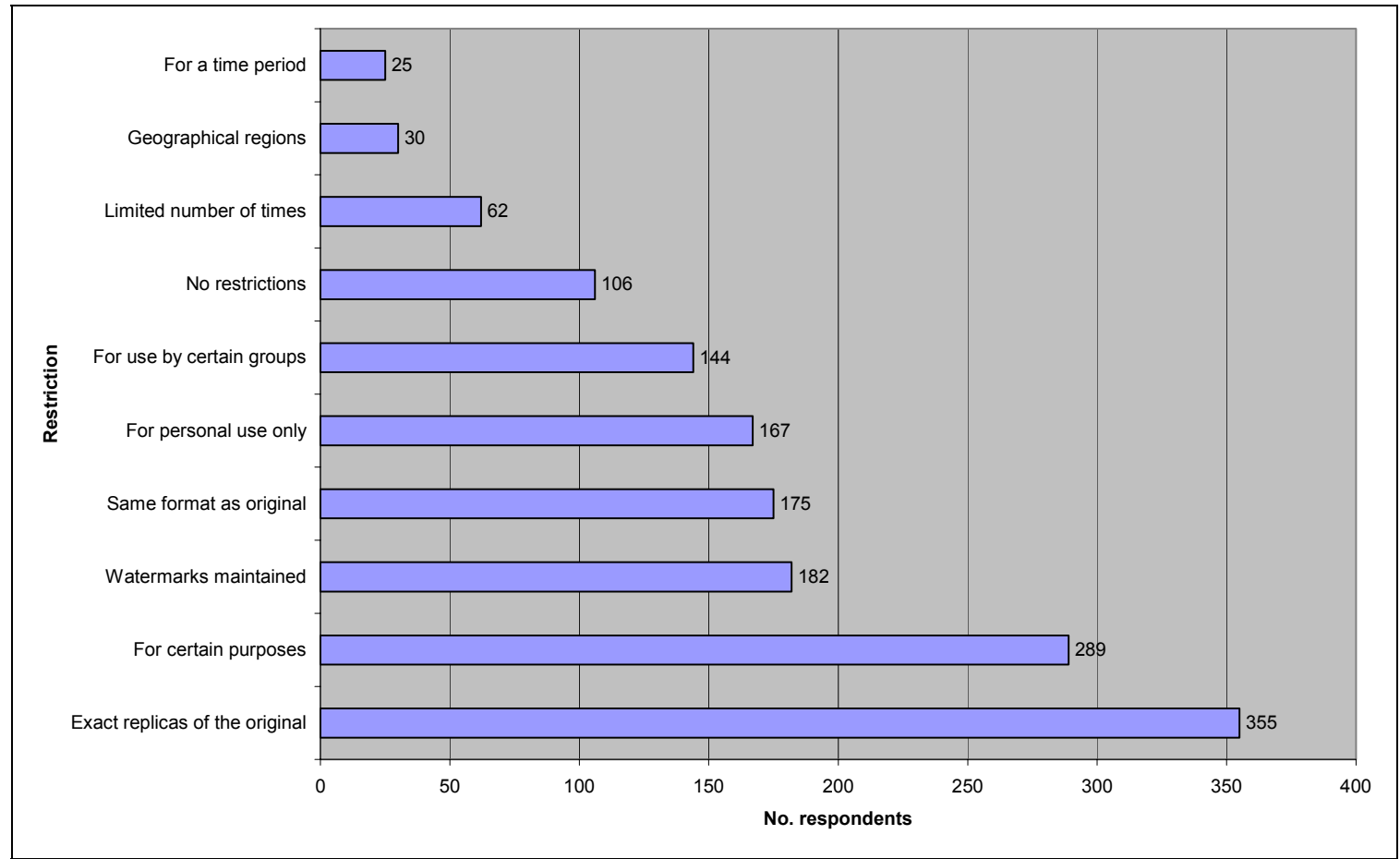

Figure 4 Restrictions academics wanted to place over their own research papers

Just over 20\% (106) of all respondents selected the "no restrictions" option. However $37(35 \%)$ of these did also select another restriction. This may mean that some respondents did not view the restriction options on the list as 'restrictive'. The total number of respondents selecting only the "no restrictions" option was 69 , or $13 \%$ of the total. The remaining $88 \%$ of respondents required some restriction over the use of their works. This indicates that simply releasing works into the 'public domain' for use by anyone for any purpose is not an option for academics. 
The largest group of respondents (67\%) wanted reproductions of their work to be exact replicas of the original ("the text must not be altered in any way"). This is in line with authors' moral rights under s. 80 of the CDPA 1988. It could have been that some respondents interpreted this question to mean that they wanted to limit reproduction of their work to the entire work (i.e., not parts). However, the fact that just under $73 \%$ of respondents indicated in the previous question that users may excerpt from their works freely implies that the interpretation of this question was as intended.

Fifty-five per cent of respondents wanted the use of their work to be limited to certain purposes (e.g., teaching, research or non-commercial). This was a considerable number and one of only two restrictions on which more than $50 \%$ of the respondents agreed.

About one-third (34\%) of respondents felt that existing watermarks or security features should be maintained. Slightly fewer (33\%) wanted reproductions to adopt the same format as the original (e.g., PDF). These results may further echo respondents' strength of feeling about copies being exact replicas of the original.

Thirty-one per cent believed their works should only be used for personal purposes. Twenty-seven per cent felt that usage should be limited to certain specified groups (e.g., only for use by educationalists). Much smaller numbers $(12 \%, 6 \%$ and $5 \%)$ expressed an interest in restricting usage of their works to a limited number of times, to certain geographic regions, or for limited time periods respectively.

\section{Conditions}

The list contained six conditions (including "no conditions") and respondents were asked to select those they would like to apply to the usage of their open-access research papers. The responses are given in Figure 5 below.



Figure 5 Conditions academics wanted to place on the use of their own research papers

A similar number of respondents stated they required 'no conditions' (111) on the use of their works as those requiring 'no restrictions' (106). However, as with the 'no restrictions' option, a large number of respondents (in this case 50\% (56)) did actually select a condition from the list. Of this $56,52(93 \%)$ selected the 'attribution' condition. 
Overall, 432 respondents (81\%) specified that they expected to be attributed as the author of their research papers. No other condition or restriction received such consensus. Just over $30 \%$ felt that all usage of their materials should be tracked. A similar number asked that users agreed to certain terms and conditions (as in a licence agreement) before being allowed to use the work. It will be important that any rights metadata associated with a paper is enforceable and agreeing to terms and conditions may be the most appropriate way of making it so. Sixteen per cent felt that users should at least register before using the work, and a much smaller figure, eight per cent, thought that users should pay a fee.

\section{Other restrictions or conditions}

Respondents were asked whether they would want to place any other conditions or restrictions on their works that had not been listed. Fifty-one gave details of such.

Ten specified that they wouldn't want their works sold for a profit, but they were not concerned about sales that simply recouped costs. Five said that if works were sold for a profit, the author should be paid a royalty. Eight reiterated the importance of attribution, and a further four said that their works should always be properly referenced (i.e., the full bibliographic details should be attached to the work and not just the author's name). One respondent wanted excerpts as well as full papers to be properly attributed. Another believed that: "any works using the original data [should] include myself or my team as coauthors of the follow-up publication." In the same vein, one academic wanted to ensure that any limitations they placed on their works were also true of derivative works - in GNU Public Licence style. Four felt that any modifications to the original work should be clearly indicated with a link back to the original, unmodified version.

Seven respondents wanted greater restrictions over their works. Three of these felt that anyone using the paper should inform the author out of courtesy. One suggested their articles should be read-only and another wanted to disable 'cut-and-paste'. One academic felt that their permission should be sought for "any usage beyond simple display and personal printing", another went one step further and suggested that nothing could be done without permission. Finally, two felt that permission should be sought for either substantive alterations to the text, annotation or aggregation.

\section{A comparison between archivers and non-archivers}

One aim of the RoMEO Project is that the development of rights metadata will encourage the take-up of self-archiving amongst academic authors. It was therefore important that non-archivers' copyright protection needs were considered carefully. Thus, an analysis of the permissions, restrictions and conditions imposed by archivers and non-archivers was performed. It was hoped that this would show whether there was any difference in the level of protection required by the two groups.

\section{Permissions allowed by archivers and non-archivers}

Of the 226 respondents that had not previously self-archived, 215 specified what they would consider to be acceptable use of any articles they made freely available on the web. Of the 310 respondents that had previously self-archived research papers, 309 indicated the uses they would allow others to make of their works. The results of the two groups' are illustrated in Figures 6 and 7. 




Figure 6 Permissions allowed by archivers



Figure 7 Permissions allowed by non-archivers

It can be seen at a glance that those that had previously self-archived were more permissive regarding the activities listed than those that had not. Table 12 below indicates in bold the most common preference for each permission by archivers and non-archivers.

\begin{tabular}{|l|c|c|c|c|c|c|}
\hline & \multicolumn{2}{|c|}{ Freely } & \multicolumn{2}{c|}{ Limited } & \multicolumn{2}{c|}{ Not at all } \\
\hline & Archivers & $\begin{array}{c}\text { Non- } \\
\text { archivers }\end{array}$ & Archivers & $\begin{array}{c}\text { Non- } \\
\text { archivers }\end{array}$ & Archivers & $\begin{array}{c}\text { Non- } \\
\text { archivers }\end{array}$ \\
\hline Aggregate & $33 \%$ & $33 \%$ & $\mathbf{6 0 \%}$ & $\mathbf{5 5 \%}$ & $7 \%$ & $13 \%$ \\
\hline Annotate & $33 \%$ & $29 \%$ & $\mathbf{5 0 \%}$ & $\mathbf{4 5 \%}$ & $17 \%$ & $27 \%$ \\
\hline
\end{tabular}




\begin{tabular}{|l|c|c|c|c|c|c|}
\hline Copy & $\mathbf{4 5 \%}$ & $31 \%$ & $40 \%$ & $\mathbf{3 5 \%}$ & $15 \%$ & $34 \%$ \\
\hline Display & $\mathbf{9 4 \%}$ & $\mathbf{8 4 \%}$ & $6 \%$ & $14 \%$ & $0 \%$ & $2 \%$ \\
\hline Excerpt & $\mathbf{7 3 \%}$ & $\mathbf{6 4 \%}$ & $27 \%$ & $32 \%$ & $1 \%$ & $4 \%$ \\
\hline Give & $\mathbf{7 8 \%}$ & $\mathbf{6 6 \%}$ & $19 \%$ & $28 \%$ & $3 \%$ & $6 \%$ \\
\hline Lease & $14 \%$ & $26 \%$ & $\mathbf{4 3 \%}$ & $\mathbf{4 1 \%}$ & $42 \%$ & $33 \%$ \\
\hline Lend & $\mathbf{7 2 \%}$ & $\mathbf{6 2 \%}$ & $24 \%$ & $31 \%$ & $4 \%$ & $8 \%$ \\
\hline Modify & $15 \%$ & $11 \%$ & $\mathbf{5 2 \%}$ & $\mathbf{4 5 \%}$ & $33 \%$ & $44 \%$ \\
\hline Print & $\mathbf{8 3 \%}$ & $\mathbf{5 8 \%}$ & $17 \%$ & $35 \%$ & $0 \%$ & $7 \%$ \\
\hline Save & $\mathbf{7 8 \%}$ & $\mathbf{4 6 \%}$ & $18 \%$ & $35 \%$ & $4 \%$ & $19 \%$ \\
\hline Sell & $7 \%$ & $11 \%$ & $38 \%$ & $39 \%$ & $\mathbf{5 5 \%}$ & $\mathbf{5 0 \%}$ \\
\hline
\end{tabular}

Table 12 Percentage of archivers and non-archivers selecting each permission.

It can be seen that for every permission except copy, the majority group of both archivers and nonarchivers agreed on the degree to which that permission could be performed (i.e. freely, limited or not at all). However, in every case, the majority agreement amongst archivers was higher than amongst nonarchivers. The 'save' permission saw the greatest disparity between the consensus groups. Thirty-two per cent more archivers (78\%) were convinced that saving should be allowed freely with self-archived works. Only $46 \%$ of non-archivers shared this conviction. Similarly $25 \%$ more archivers felt that printing should be allowed freely. Eighty-three per cent of archivers chose this option compared with just $58 \%$ of non-archivers.

Table 13 lists the permissions in order of greatest agreement amongst archiving and non-archiving respondents.

\begin{tabular}{|l|c|c|c|c|c|c|}
\hline Permission & \multicolumn{3}{|c|}{ Archivers } & \multicolumn{3}{c|}{ Non archivers } \\
\hline & $\begin{array}{c}\text { \%age } \\
\text { agreeing }\end{array}$ & Option & Rank & $\begin{array}{c}\text { \%age } \\
\text { agreeing }\end{array}$ & Option & Rank \\
\hline Display & 94 & Freely & 1 & 84 & Freely & 1 \\
\hline Give & 78 & Freely & 3 & 64 & Freely & 2 \\
\hline Excerpt & 73 & Freely & 5 & 63 & Freely & 3 \\
\hline Lend & 72 & Freely & 6 & 60 & Freely & 4 \\
\hline Print & 83 & Freely & 2 & 58 & Freely & 5 \\
\hline Aggregate & 60 & $\begin{array}{c}\text { Limited or } \\
\text { conditional }\end{array}$ & 7 & 53 & $\begin{array}{l}\text { Limited or } \\
\text { conditional }\end{array}$ & 6 \\
\hline Sell & 55 & Not at all & 8 & 49 & Not at all & 7 \\
\hline Save & 78 & Freely & $3=$ & 45 & Freely & 8 \\
\hline Annotate & 50 & $\begin{array}{c}\text { Limited or } \\
\text { conditional }\end{array}$ & 9 & 44 & $\begin{array}{c}\text { Limited or } \\
\text { conditional }\end{array}$ & $9=$ \\
\hline Modify & 52 & $\begin{array}{c}\text { Limited or } \\
\text { conditional }\end{array}$ & 10 & 44 & $\begin{array}{c}\text { Limited or } \\
\text { conditional }\end{array}$ & $9=$ \\
\hline Lease & 43 & $\begin{array}{c}\text { Limited or } \\
\text { conditional }\end{array}$ & 11 & 39 & $\begin{array}{c}\text { Limited or } \\
\text { conditional }\end{array}$ & 11 \\
\hline Copy & 45 & Freely & 12 & 34 & $\begin{array}{c}\text { Limited or } \\
\text { conditional }\end{array}$ & 12 \\
\hline
\end{tabular}

Table 13 Permissions in order of agreement-archivers and non-archivers

It can be seen that there were some differences between the way the two groups ranked the permissions. However, the greatest agreement in both groups was over the 'display' permission, and the least agreement was over annotate, modify, lease and copy. The non-archivers agreed on the remaining permissions in the following order: give, excerpt, lend, print, aggregate, sell and save. Whereas the archivers ranked them: print, give/save, excerpt, lend, aggregate and sell. The notable differences occur with the print permission that for the archivers ranked the highest after display, but for the non-archivers ranked fifth overall; and the save permission that archivers ranked third, and non-archivers ranked eighth. 
Non-archivers are more likely to have never used self-archived works themselves (see RoMEO Studies [36]) thus it may have been that they were unaware of the importance of printing and saving to the effective use of self-archived works.

Chi-square tests were performed on each permission to test the null hypothesis that there was no difference between the permissions allowable by archivers and non-archivers. Highly significant differences (at the 1\% level) were found for eight of the permissions (display, give, excerpt, print, save, annotate, lease and copy). Difference at the 5\% level was found for lend. There was no significant difference between archivers and non-archivers on the aggregate and sell permissions.

\section{Restrictions imposed by archivers and non-archivers}

A comparison of the percentage of archivers and non-archivers that selected restrictions to be enforced over freely available works is given in Table 14. Chi-squared tests were then performed on the responses to each restriction by both groups.

\begin{tabular}{|l|c|c|c|c|}
\hline Restrictions & \multicolumn{2}{|c|}{ Archivers } & \multicolumn{2}{c|}{ Non-archivers } \\
\hline & $\mathbf{\%}$ & Rank & $\mathbf{\%}$ & Rank \\
\hline Exact replicas of the original & $63 \%$ & 1 & $74 \%$ & 1 \\
\hline For certain purposes & $49 \%$ & 2 & $62 \%$ & 2 \\
\hline Same format as original & $29 \%$ & 3 & $39 \%$ & 4 \\
\hline For personal use only & $29 \%$ & 4 & $36 \%$ & 5 \\
\hline Watermarks maintained & $28 \%$ & 5 & $44 \%$ & 3 \\
\hline For use by certain groups & $24 \%$ & 6 & $32 \%$ & 6 \\
\hline No restrictions & $22 \%$ & 7 & $18 \%$ & 7 \\
\hline Limited number of times & $8 \%$ & 8 & $17 \%$ & 8 \\
\hline Geographical regions & $4 \%$ & 9 & $8 \%$ & 10 \\
\hline For a time period & $1 \%$ & 10 & $10 \%$ & 9 \\
\hline
\end{tabular}

Table 14 Restrictions imposed by archivers and non-archivers

A higher percentage of non-archivers selected every restriction except 'no restrictions'. Indeed, there was no significant difference between the number of archivers selecting 'no restrictions' and the number of non-archivers. Neither were there significant differences between the two groups on 'for use by certain groups', 'for personal use' and 'geographical regions'. All other restrictions showed significant differences. The variations in percentages ranged from $4 \%$ on geographical regions (not significant) up to $16 \%$ on watermarks (significant at the $1 \%$ level). Indeed the rankings were fairly similar except for the maintenance of watermarks and other security features which came third on the non-archivers' list and fifth on the archivers' list. Overall, six restrictions were selected by a third or more of the non-archivers, and only two restrictions were selected by a third or more of the archivers.

\section{Conditions imposed by archivers and non-archivers}

A comparison of the percentage of archivers and non-archivers that selected conditions to be enforced over freely available works is given in Table 15 below. Chi-square tests were then performed on the response to each condition by both groups.

\begin{tabular}{|l|c|c|c|c|}
\hline Conditions & \multicolumn{2}{|c|}{ Archivers } & \multicolumn{2}{c|}{ Non-archivers } \\
\hline & $\mathbf{\%}$ & Rank & $\mathbf{\%}$ & Rank \\
\hline Author must be attributed & $81 \%$ & 1 & $83 \%$ & 1 \\
\hline Usage tracking & $25 \%$ & 2 & $43 \%$ & 2 \\
\hline Agree terms \& conditions & $24 \%$ & 3 & $42 \%$ & 3 \\
\hline Users must register & $11 \%$ & 5 & $25 \%$ & 4 \\
\hline No conditions & $23 \%$ & 4 & $18 \%$ & 5 \\
\hline Fee paid & $4 \%$ & 6 & $13 \%$ & 6 \\
\hline
\end{tabular}

Table 15 Conditions imposed by archivers and non-archivers 
Once again, every condition was selected by a higher percentage of non-archivers than archivers except 'no conditions'. 'No conditions' was selected by $23 \%$ of archivers, and $18 \%$ of non-archivers. A chisquare test showed that this difference was not significant. Percentage differences for the other five categories ranged from two per cent on author attribution to $18 \%$ on usage tracking and agreeing terms and conditions. All were significant differences at the $1 \%$ level except attribution, for which there was no significant difference in response from archivers and non-archivers. However, whilst three usage conditions were selected by over a third of non-archiving respondents, only attribution was selected by more than a third of archiving respondents.

\section{Discussion}

The main purpose of the author survey was to ascertain how academic authors wanted to protect their self-archived research papers in order to develop the rights metadata. The analysis of the permissions, restrictions and conditions (P, R and C's) results was therefore of great importance. At one end of the spectrum, academics could be allowed to select any limit and/or condition. Whilst this would cater for $100 \%$ of academics' needs, it would amount to hundreds of combinations of rights metadata that would overburden data providers and service providers. At the other end of the spectrum, we could provide a single rights statement based on the fact that most academics allowed $\mathrm{x}, \mathrm{y}$, and $\mathrm{z}$ permissions, under restrictions, a, b and c, and conditions, $\mathrm{d}$, e, and f. However this would actually only cater for a small percentage of academics and would be quite inflexible.

The results showed that whilst there was some agreement on a number of $\mathrm{P}, \mathrm{R}$ and $\mathrm{C}$ 's, the agreement in many cases was under $50 \%$. This indicates that academics have a wide range of views on the protection their self-archived works require, and so a certain amount of flexibility in the metadata would be appropriate. At the same time, the project Advisory Board advised the team to 'lead' rather than 'follow' in the design of a rights metadata solution. A middle-ground balancing simplicity and flexibility was clearly needed. It was decided that any P, R and C's receiving over $50 \%$ agreement would be selected for the metadata solution, and any receiving over $60 \%$ agreement would be made a mandatory element.

\section{Permissions}

There was over 50\% agreement on all permissions except copy, modify, annotate and lease. It was believed that there was a semantic problem with the word copy. Indeed ODRL itself does not use the term 'copy', it only allows for 'duplicate' in the 'document management' category of permissions (i.e., duplicate for back-up purposes). The RoMEO Project inserted copy as an additional permission because it felt that 'print' did not adequately express on-photocopying or other analogue copying, and 'save' implied saving to disk for personal use and not mounting on a publicly available server (i.e. mirroring a web page). However, it is clear that 'copy' is not a suitable term for rights metadata without considerable clarification. In reality, copying from digital works only really falls into two categories: print and save.

The majority group of respondents felt that annotate, modify and lease could only be performed under certain limits or conditions indicating a certain amount of uncertainty about these activities. Annotate is (of itself) an unregulated activity under UK copyright law. Any annotations do modify a work to some degree. In another part of the survey, only $16 \%$ of academics-as-users said they expected to annotate others' works freely [15]. Modification (by virtue of being an adaptation) is regulated under copyright law, and only $13 \%$ of academics-as-authors wished to allow others to modify their works freely.

The lease permission was ranked by the smallest number of respondents (500) perhaps in itself indicating that it was considered irrelevant by some respondents. Indeed $67 \%$ of academics-as-users said that they would not expect to do this at all with research papers (see RoMEO Studies [15]). The concept of leasing a work is covered to some degree by 'sell' and, if instituted, by a 'purpose' restriction of non-commercial. Copy, annotate, and lease were thus omitted from the rights metadata.

Over $60 \%$ of respondents (over two-thirds in most cases) agreed that display, give, print, excerpt, lend, and save, should be permitted freely. Although there was less agreement on these permissions from nonarchiving authors (see Table 13), there was slightly more agreement amongst non-archiving users (see 
RoMEO Studies 3 [15]). This demonstrated that there was perhaps no great moral objection to them, but an apprehension due to inexperience. Between 50 and $60 \%$ felt that aggregate and modify could be permitted under limit or condition, and that sell should be prohibited.

It was therefore decided to make display, give, print, excerpt, lend and save mandatory permissions, to make aggregate an optional permission, and to prohibit sell. The only concern with the resulting list was the 'lend' permission which seemed to be pre-empted by 'give'. If I am happy to allow my work to be given away, I would surely be happy for it to be given away and later returned.

\section{Restrictions}

Over fifty per cent of respondents agreed on two restrictions: 67\% selected 'exact replicas' and 55\% selected 'for certain purposes'. The fraction of respondents selecting watermarks, format, personal use and for use by certain groups reduced to about one-third. Of these four, the latter two 'personal use' and 'use by certain groups' could be catered for by the 'for certain purposes' restriction if the attributes for this element were carefully chosen. For example, the purpose could be 'for personal use', or 'for educational purposes' implying that only educationalists could use it.

The by-passing of watermarks and security features will soon be made illegal under the national implementation of the EU Copyright Directive. Therefore, this would not need to be incorporated in the rights metadata. Respondents' anxiety to maintain the format of the original (e.g., PDF) may here be closely linked to their desire to see only exact replicas of the work made. (Interestingly, this was the only restriction that academics-as-authors ranked higher than academics-as-users. Users placed it in 6th place at $32 \%$ and authors placed it in 4th place with $33 \%$ - see RoMEO Studies [15]).

The time period, geographical regions, and limited number of times restrictions were clearly considered irrelevant by respondents.

In summary, it would seem that there are two principle restrictions that academics wish to make over their open-access works: exact replicas and for certain purposes. The exact replicas requirement would need to be carefully defined to encompass exact content replicas, so as not to be misinterpreted as 'Same format as the original' which was considered irrelevant by the majority of respondents. The problem with the 'for certain purposes' restriction was that no 'purpose' options were given in the questionnaire and thus agreed upon by respondents. The example given for the question was 'e.g. teaching, research or noncommercial' so it may be inferred that these purposes appealed to respondents. Twenty-five per cent of respondents indicated that they would allow their works to be sold under certain limits or conditions. When respondents were asked to specify conditions or restrictions not previously listed, ten of the 51 respondents indicated that they would not want their work sold for a profit implying that not all sales should be prohibited, only the commercial ones.

Whilst it is understandable that limiting usage of works to teaching or research purposes should appeal to academics working in a teaching and research environment, in practice such terms are hard to define. In the broadest sense, using a paper in a business presentation could be considered 'teaching', and many uses could be considered 'research'. It is interesting that the EU Copyright Directive excludes 'commercial research' from any fair dealing defence. It could be concluded that as long as academics are given the option of limiting usage to 'non-commercial' purposes, they are receiving at least as much protection as the EU Directive deems necessary. It would be counter to the open-access movement to place even greater restrictions on the usage of material than copyright law itself allows.

\section{Conditions}

The 'attribution' condition was requested by $81 \%$ of respondents. About one-third of respondents selected usage tracking and agreeing to terms and conditions prior to use. These are primarily functions provided by publishers of electronic full-text. Very few respondents thought that users must register or pay a fee before using self-archived works. 


\section{Summary}

In summary, the following permissions, restrictions and conditions most closely represented the requirements of academics for the protection of their open-access works (see Table 16).

\begin{tabular}{|l|l|l|}
\hline Permissions & Restrictions & Conditions \\
\hline Display & Exact replicas & Attribution \\
\hline Give & $\begin{array}{l}\text { For non-commercial } \\
\text { purposes (optional) }\end{array}$ & \\
\hline Print & & \\
\hline Excerpt & & \\
\hline Save & & \\
\hline [Lend] & & \\
\hline Aggregate (optional) & & \\
\hline Sell (prohibit) & & \\
\hline
\end{tabular}

Table 16 The permissions, restrictions and conditions required over open-access works

The next question was: which restrictions and conditions should apply to which permissions? The majority of respondents wanted to allow the mandatory permissions 'freely'. However, at the same time, similarly large majorities wanted to limit copies to exact replicas and to be attributed as the author. It could be assumed, therefore, that academics did not see such constraints as 'limits'. It was therefore concluded that academics would want the R and C's to apply to all permissions, rather than to selected ones. Also, from a practical perspective, it would have become very complicated and time consuming if an academic had to select separate restrictions and conditions for each of the permission $\mathrm{s} / \mathrm{he}$ wished to allow. It was decided therefore that the R's and C's should apply to all permissions. Thus, if academics wished to permit aggregation, they could do so, but the exact replicas and attribution limits would apply to all of them - as would the non-commercial restriction if chosen.

\section{Responsibility for the creation of rights metadata}

It had been assumed throughout the survey design and analysis that academics would own the rights in their research papers and that they would therefore be generating the rights metadata pertaining to those papers. However, there may well be three other scenarios. Firstly, it may be that academics have assigned their copyright to publishers, but that the publisher allows self-archiving under certain conditions. In this case, the publishers' conditions would need to form a part of the rights metadata. Secondly, it may be that the author's employer owns copyright. Traditionally, universities have not asserted copyright in academics work. However, a number of groups are lobbying for a change in university copyright management to encourage universities to stake their claim over the copyright in research outputs. In such a scenario, the employer would have a say in the creation of the rights metadata.

Finally, it may be that institutions establishing e-print archives decide that they will only accept documents that can be used in certain ways (i.e., users must be allowed to print, excerpt and save). In this scenario, the archive may restrict the rights metadata options open to the author - or refuse to host papers that don't meet the required standards. This would certainly make the implementation and usage of rights metadata far simpler for Data Providers and Service Providers. The former could embed a standard form of wording on each e-print, making communication with the end user much easier. The latter, would know that any e-prints at a particular archive are available under predetermined conditions, and could build services accordingly.

\section{Comparison of copyright law provisions and academics' requirements}

Tables 17, 18 and 19 compare the $\mathrm{P}, \mathrm{R}$ and C's provided by copyright law over research papers in general with those actually required by academics over their open-access papers.

\begin{tabular}{|l|l|l}
\hline Permission & Copyright law & RoMEO \\
\hline
\end{tabular}




\begin{tabular}{|l|l|l|}
\hline $\begin{array}{l}\text { name } \\
\text { (elements) }\end{array}$ & Academic authors \\
\hline Display & LIMITED & LIMITED \\
\hline Print & LIMITED & LIMITED \\
\hline Modify & LIMITED & OMITTED \\
\hline Excerpt & LIMITED & LIMITED \\
\hline Annotate & LIMITED & $\begin{array}{l}\text { LIMITED (VIA } \\
\text { MODIFY) }\end{array}$ \\
\hline Aggregate & LIMITED & LIMITED \\
\hline Sell & LIMITED & PROHIBITED \\
\hline Lend & LIMITED & LIMITED \\
\hline Give & LIMITED & LIMITED \\
\hline Lease & PROHIBITED & OMITTED \\
\hline Duplicate & LIMITED & OMITTED \\
\hline Save & LIMITED & LIMITED \\
\hline
\end{tabular}

Table 17 Permissions used in the survey

\begin{tabular}{|l|l|l|}
\hline $\begin{array}{l}\text { ODRL } \\
\text { Constraint } \\
\text { name } \\
\text { (element) }\end{array}$ & Copyright Law & $\begin{array}{l}\text { RoMEO } \\
\text { Academic authors }\end{array}$ \\
\hline Individual & Y & $\mathrm{N}$ \\
\hline Group & Y & $\mathrm{N}$ \\
\hline Count & Y & $\mathrm{N}$ \\
\hline Spatial & $\mathrm{Y}$ & $\mathrm{N}$ \\
\hline DateTime & $\mathrm{Y}$ & $\mathrm{N}$ \\
\hline Quality & $\mathrm{Y}$ & $\mathrm{Y}$ (exact replicas) \\
\hline Format & $\mathrm{N}$ & $\mathrm{N}$ \\
\hline Watermark & $\mathrm{N}$ & $\mathrm{N}$ \\
\hline Purpose & $\mathrm{Y}$ & $\begin{array}{l}\mathrm{Y} \text { (non- } \\
\text { commercial) }\end{array}$ \\
\hline
\end{tabular}

Table 18 Constraints (renamed restrictions) used in the survey

\begin{tabular}{|l|l|l|}
\hline $\begin{array}{l}\text { ODRL } \\
\text { Requiremen } \\
\text { t name } \\
\text { (elements) }\end{array}$ & Copyright Law & $\begin{array}{l}\text { RoMEO } \\
\text { Academic authors }\end{array}$ \\
\hline Payment & Y & N \\
\hline Accept & Y & N \\
\hline Register & Y & N \\
\hline Attribution & Y & Y \\
\hline Tracked & Y & N \\
\hline
\end{tabular}

Table 19 Requirements (renamed conditions) used in the survey

A cursory glance at the comparison of permissions allowed by copyright law, and academic authors does not reveal any startling differences. However, what is important is not the fact that permissions are limited, but the extent of those limits. Although academic authors wanted to place limits on their permissions, e.g. printing, the limits were not onerous: exact replicas of the original (possibly for noncommercial purposes) and with attribution of the author. Indeed, it is arguable that most academics did not see these as limits at all. Copyright law utilised seven of the listed ODRL restrictions, whereas most academic authors required only two; the law also utilised all five of the listed conditions, whereas most academic authors required only one. 


\section{Conclusions}

Our investigations indicate that the protection offered research papers by copyright law exceeds the protection required by most academic authors. It also raises concerns about the level of protection enforced by e-journal licence agreements. Most academic authors are primarily interested in preserving their moral rights. In UK law, there are two main moral rights: i) the right to be identified as author, and ii) the right to object to derogatory treatment of a work. An overwhelming majority of academics asked to be identified as author (the 'attribution' requirement), and over two-thirds wanted copies to be exact replicas of the original content (thus minimising the chance of derogatory treatment). The interest in limiting modification and aggregation may also have its roots in such moral rights considerations. By contrast, far fewer (53\%) were concerned about their so-called 'economic rights' by objecting to the sell permission.

Although non-archivers required more protection for their (hypothetical) open-access papers than archivers, we have shown that non-archivers' primary concerns about open-access are not concerns about the misuse of their paper, but the fear of not being published. It would seem appropriate therefore for this issue to be addressed in the first instance by educational campaigns. Once they have the confidence to self-archive, their protection requirements may decrease.

We believe that the protection offered by the proposed rights metadata promises to provide adequate protection for academic authors, whilst granting end-users the 'open-access' to the research literature they desire.

\section{APPENDIX 1}

Permissions used in the survey

\begin{tabular}{|c|c|c|c|}
\hline $\begin{array}{l}\text { ODRL Permission type } \\
\text { (Abstract entities) }\end{array}$ & $\begin{array}{l}\text { Permission } \\
\text { name (elements) }\end{array}$ & $\begin{array}{l}\text { Selected } \\
\text { for } \\
\text { survey? }\end{array}$ & $\begin{array}{l}\text { Wording in survey } \\
\text { (including example) }\end{array}$ \\
\hline \multirow[t]{4}{*}{ Usage } & Display & $\mathrm{Y}$ & $\begin{array}{l}\text { Display (e.g. may be viewed } \\
\text { on screen) }\end{array}$ \\
\hline & Print & $\mathrm{Y}$ & $\begin{array}{l}\text { Print (e.g. copies may be } \\
\text { printed out) }\end{array}$ \\
\hline & Play & $\mathrm{N}$ & \\
\hline & Execute & $\mathrm{N}$ & \\
\hline \multirow[t]{4}{*}{ Reuse } & Modify & $\mathrm{Y}$ & $\begin{array}{l}\text { Modify (e.g. may be } \\
\text { translated or a derivative } \\
\text { work created) }\end{array}$ \\
\hline & Excerpt & $\mathrm{Y}$ & $\begin{array}{l}\text { Excerpt (e.g. a short passage } \\
\text { may be quoted) }\end{array}$ \\
\hline & Annotate & $\mathrm{Y}$ & $\begin{array}{l}\text { Annotate (e.g. editorial or } \\
\text { peer commentary may be } \\
\text { inserted) }\end{array}$ \\
\hline & Aggregate & $\mathrm{Y}$ & $\begin{array}{l}\text { Aggregate (e.g. may be } \\
\text { compiled into an anthology ) }\end{array}$ \\
\hline \multirow[t]{4}{*}{ Transfer } & Sell & $\mathrm{Y}$ & $\begin{array}{l}\text { Sell (e.g. either on a cost- } \\
\text { recovery basis or as a } \\
\text { commercial enterprise) }\end{array}$ \\
\hline & Lend & $\mathrm{Y}$ & $\begin{array}{l}\text { Lend (e.g. a printed copy } \\
\text { may be loaned by a library) }\end{array}$ \\
\hline & Give & $\mathrm{Y}$ & $\begin{array}{l}\text { Give (e.g. copies may be } \\
\text { forwarded to colleagues ) }\end{array}$ \\
\hline & Lease & $\mathrm{Y}$ & Lease (e.g. may be loaned or \\
\hline
\end{tabular}




\begin{tabular}{|l|l|l|l|}
\hline & & licensed for a fee) \\
\hline Asset management & Move & N & \\
\hline & Duplicate & Y & $\begin{array}{l}\text { Copy (e.g. mount another } \\
\text { copy on the web) }\end{array}$ \\
\hline & Delete & N & \\
\hline & Verify & N & \\
\hline & Backup & N & \\
\hline & Restore & N & $\begin{array}{l}\text { Save (e.g. may be saved to } \\
\text { disk) }\end{array}$ \\
\hline & Save & Y & \\
\hline & Install & N & \\
\hline & Uninstall & N & \\
\hline
\end{tabular}

Constraints (renamed restrictions) used in the survey

\begin{tabular}{|c|c|c|c|}
\hline $\begin{array}{l}\text { ODRL Constraint } \\
\text { type (Abstract } \\
\text { entities) } \\
\end{array}$ & $\begin{array}{l}\text { ODRL Constraint } \\
\text { name (element) }\end{array}$ & $\begin{array}{l}\text { Selected } \\
\text { for } \\
\text { survey? }\end{array}$ & $\begin{array}{l}\text { Wording for survey } \\
\text { (including example) }\end{array}$ \\
\hline \multirow[t]{2}{*}{ User } & Individual & $\mathrm{Y}$ & $\begin{array}{l}\text { For personal use only (e.g. } \\
\text { user can't distribute copies to } \\
\text { others) }\end{array}$ \\
\hline & Group & $\mathrm{Y}$ & $\begin{array}{l}\text { For use by certain groups } \\
\text { (e.g. only for use by } \\
\text { educationalists) }\end{array}$ \\
\hline \multirow[t]{8}{*}{ Device } & $\mathrm{CPU}$ & $\mathrm{N}$ & \\
\hline & Network & $\mathrm{N}$ & \\
\hline & Screen & $\mathrm{N}$ & \\
\hline & Storage & $\mathrm{N}$ & \\
\hline & Memory & $\mathrm{N}$ & \\
\hline & Printer & $\mathrm{N}$ & \\
\hline & Software & $\mathrm{N}$ & \\
\hline & Hardware & $\mathrm{N}$ & \\
\hline \multirow[t]{3}{*}{ Bounds } & Count & $\mathrm{Y}$ & $\begin{array}{l}\text { Limited number of times } \\
\text { (e.g. print up to four copies, } \\
\text { or save once) }\end{array}$ \\
\hline & Range & $\mathrm{N}$ & \\
\hline & Spatial & $\mathrm{Y}$ & $\begin{array}{l}\text { Limited to certain } \\
\text { geographical regions (e.g. } \\
\text { not to be used in countries } \\
\text { with sanctions) }\end{array}$ \\
\hline \multirow[t]{3}{*}{ Temporal } & DateTime & $\mathrm{Y}$ & $\begin{array}{l}\text { Only available for a certain } \\
\text { period of time (e.g. must be } \\
\text { removed after } 5 \text { years) }\end{array}$ \\
\hline & Accumulated & $\mathrm{N}$ & \\
\hline & Interval & $\mathrm{N}$ & \\
\hline Rights & Transfer permission & $\mathrm{N}$ & \\
\hline \multirow[t]{2}{*}{ Aspect } & Quality & $\mathrm{Y}$ & $\begin{array}{l}\text { Copies must be exact replicas } \\
\text { of the original text (e.g. the } \\
\text { text must not be altered in } \\
\text { any way) }\end{array}$ \\
\hline & Format & $\mathrm{Y}$ & $\begin{array}{l}\text { Copies must be in the same } \\
\text { format as the original (e.g. }\end{array}$ \\
\hline
\end{tabular}




\begin{tabular}{|c|c|c|c|}
\hline & & & $\begin{array}{l}\text { only PDF copies can be } \\
\text { made) }\end{array}$ \\
\hline & Unit & $\mathrm{N}$ & \\
\hline & Watermark & $\mathrm{Y}$ & $\begin{array}{l}\text { Existing watermarks or } \\
\text { security features must be } \\
\text { maintained (e.g. all copies } \\
\text { must retain the security } \\
\text { features of the original) }\end{array}$ \\
\hline \multirow[t]{3}{*}{ Target } & Purpose & $\mathrm{Y}$ & $\begin{array}{l}\text { Only for certain purposes } \\
\text { (e.g. teaching, research or } \\
\text { non-commercial) }\end{array}$ \\
\hline & Industry & $\mathrm{N}$ & \\
\hline & ReContext & $\mathrm{N}$ & \\
\hline
\end{tabular}

Requirements (renamed conditions) used in the survey

\begin{tabular}{|l|l|l|l|}
\hline $\begin{array}{l}\text { ODRL } \\
\text { Requirement type } \\
\text { (Abstract entities) }\end{array}$ & $\begin{array}{l}\text { ODRL Requirement } \\
\text { name (elements) }\end{array}$ & $\begin{array}{l}\text { Selected } \\
\text { for } \\
\text { survey? }\end{array}$ & $\begin{array}{l}\text { Wording for survey } \\
\text { (including example) }\end{array}$ \\
\hline Fee & Payment & Y & $\begin{array}{l}\text { Fee paid (e.g. a fee per copy, } \\
\text { or pay for access) }\end{array}$ \\
\hline & PrePay & N & \\
\hline & PostPay & N & N \\
\hline Interactions & PerUse & Y & $\begin{array}{l}\text { Users must agree to certain } \\
\text { terms and conditions (e.g. a } \\
\text { click-through licence) }\end{array}$ \\
\hline & Accept & Y & $\begin{array}{l}\text { Users must register (e.g. with } \\
\text { a service provider) }\end{array}$ \\
\hline Usage & Register & Y & $\begin{array}{l}\text { Author must be attributed } \\
\text { (e.g. your name should } \\
\text { always be clearly displayed } \\
\text { on the article) }\end{array}$ \\
\hline & Attribution & $\begin{array}{l}\text { Usage tracking (e.g. all usage } \\
\text { of your article should be } \\
\text { tracked) }\end{array}$ \\
\hline
\end{tabular}

\section{References}

1 The Copyright Licensing Agency. (2003) URL: http://www.cla.co.uk/

2 Okerson, A. (1997). "Copyright or contract?" Library Journal 122(14): 136-139.

3 Kaye, L. (1999). "Owning and licensing content - key legal issues in the electronic environment." Journal of Information Science 25(1): 7-14.

4 Richards, R. (2001). "Licensing Agreements: Contracts, the Eclipse of Copyright, and the Promise of Cooperation." The Acquisitions Librarian 89(26).

5 Anon. (2002). The Scholarly Communications Crisis [Paper given at a seminar entitled 'The Scholarly Communication Crisis - change the future!' held at Worcester College, Oxford, 8 March 2002], CURL: http://www.bodley.ox.ac.uk/ulsd/curl/advocacy.doc.

6 McGinnis, S. D. (2000). "Selling our collecting souls: How licence agreements are controlling collection management." Journal of Library Administration 31(2): 63-76.

7 ArXiv.org eprint archive. (2003) URL: http://arxiv.org/ 
8 Crow, R. (2002). The case for institutional repositories: a SPARC position paper. Washington DC, The Scholarly Publishing and Academic Resources Coalition: http://www.arl.org/sparc/IR/ir.html.

9 Harnad, S. (2001). For Whom the Gate Tolls? How and Why to Free the Refereed Research Literature Online Through Author/Institution Self-Archiving, Now.

http://cogprints.soton.ac.uk/documents/disk0/00/00/16/39/index.html.

10 Cope, B., and Robin Freeman, Ed. (2000). Digital rights management and content development. Altona, Vic., Common Ground.

11 Johnson, P. (2003). "All Wrapped Up? A Review of the Enforceability of "Shrink-wrap" and "Clickwrap" Licences in the United Kingdom and the United States." European Intellectual Property Review 25(2): 98-102.

12 Anon. What is copyleft?, Free Software Foundation Inc., http://www.gnu.org/copyleft/copyleft.html. 2002.

13 Creative Commons. (2003) URL: http://creativecommons.org/

14 (2003). RoMEO Project. URL: http://www.lboro.ac.uk/departments/ls/disresearch/romeo/index.html. 15 See: Gadd, Elizabeth, Charles Oppenheim and Steve Probets. (2003) RoMEO Studies 3: How academics expect to use open-access research papers. [To be submitted to the Journal of Library and Information Science]

16 Great Britain. (1988). Copyright, designs and patents Act 1988, Elizabeth II. London : HMSO

17 Open Digital Rights Language. http://odrl.net/ 2002

18 Lessig, L. (2002). "Free Culture. [Keynote paper presented at the Open Source Convention. 22-26 July, 2002. San Diego, CA]." http://www.oreillynet.com/pub/a/policy/2002/08/15/lessig.html.

19 Council Directive 2001/29/EC of the European Parliament and of the Council of 22 May 2001 on the Harmonisation of Certain Aspects of Copyright and Related Rights in the Information Society URL: http://www.patent.gov.uk/about/consultations/eccopyright/annexb.htm

20 Clark, C. (1990). Photo-copying : photocopying from books and journals : a guide for all users of copyright literary works. London, British Copyright Council. p.10

21 (2000). Fair dealing and library privilege: copyright for research and private study in the UK. London, Copyright Licensing Agency. http://www.cla.co.uk/copyrightvillage/fairdealing.PDF.

22 UUK vs CLA. 2001, CT71/00, 72/00, 73/00, 74/00 and 75/00. URL:

http://www.patent.gov.uk/copy/tribunal/uukvcla.pdf

23 (1998) Guidelines for Fair Dealing in an Electronic Environment. London, Joint Information Systems Committee; Publishers Association: http://www.ukoln.ac.uk/services/elib/papers/pa/fair/intro.html.

24 Council Directive 92/100/EEC of 19 November 1992 on rental right and lending right and on certain rights related to copyright in the field of intellectual property. URL:

http://europa.eu.int/ISPO/ecommerce/legal/documents/392L0100/392L0100 EN.doc and

Council Directive 2001/29/EC of the European Parliament and of the Council of 22 May 2001 on the

Harmonisation of Certain Aspects of Copyright and Related Rights in the Information Society URL:

http://www.patent.gov.uk/about/consultations/eccopyright/annexb.htm

25 United States Code. 17 USC 109. URL: http://liimirror.warwick.ac.uk/uscode/index.html

26 The Copyright and Related Rights Regulations 1996 SI 1996/2967. Reg. 10(2).

27 Great Britain, 1988. Copyright, designs and patents Act 1988, Ch. 80. Elizabeth II. London : HMSO 28 (2003). Summary table of electronic journal licences, Leicester University. URL:

http://www.le.ac.uk/li/sources/ejournal/licences.html.

29 (2003). Permitted uses of online resources, Yale University Library. URL:

http://www.library.yale.edu/journals/licensing.html.

30 (2001). Copyright Law of the United States of America and related laws contained in title 17 of the

United States Code. http://www.copyright.gov/title17/circ92.pdf. Washington, D.C., Library of Congress: US Copyright Office. S107

31 Gadd, Elizabeth., Charles Oppenheim, and Steve Probets. (2003) "RoMEO Studies 1: The impact of copyright ownership on academic author self-archiving." Journal of Documentation 59(3), 243-277.

32 See RoMEO Studies 5: Rights metadata for open archiving.

33 Gadd, Elizabeth., Charles Oppenheim, and Steve Probets. (2003) "RoMEO Studies 1: The impact of copyright ownership on academic author self-archiving." Journal of Documentation 59(3), 243-277.

34 Swan, A. (2002). Authors and electronic publishing: the ALPSP research study on authors' and readers' views of electronic research communication. West Sussex, ALPSP: 83pp.

35 See: Woodward, H., McKnight, C; Pritchett, C; Rowland, F (1997). Cafe Jus: commercial and free electronic journals user study. London, British Library. Research and Innovation Report: 1-52. See also: Tenopir, C., and Donald W. King (2002). Reading behaviour and electronic journals. Learned Publishing 15(4): 259-265. 
